\title{
NO T E S
}

\section{UNIVERSITY OF ALASKA}

GULKANA GLACIER EXPEDITION

During the summer of 1960 glaciological investigations were initiated on Gulkana Glacier in the central Alaska Range by members of the Department of Geology, University of Alaska. The programme is being supported by a grant from the National Science Foundation awarded to Dr. Troy L. Péwé, project supervisor and head, Department of Geology.

Interior Alaska is a physiographic and climatic area heretofore almost neglected in glacier studies, in contrast to southeastern Alaska. The little work that has been done indicates that the glaciers in the interior deserve attention from the standpoint of present and historical fluctuations and studies of flow, ablation, and structure. At least two glaciers in the central Alaska Range are of special interest inasmuch as they have undergone advances as rapid, or more rapid than any others in the world. Gulkana Glacier lies on the south side of the Alaska Range 4 miles east of the Richardson Highway and about 135 miles southeast of Fairbanks. This glacier was chosen on account of its accessibility, size, structure, and because a 50-year photographic record of it is available.

The glacier is 2.5 miles long and flows essentially to the south, the average width is about 1 mile. On the western side an ice fall divides the glacier roughly in half. The lower half is composed of three ice streams. The altitude of the terminus is $\mathbf{3 9 5 0}$ feet and that of the ice in the cirque areas 6500 to 7000 feet.

Paul V. Sellmann and N. W. Rutter, graduate students of the Department of Geology, University of Alaska, each ted a small field party and began investigations in the second week of June 1960. The work lasted until mid-September and was divided into two broad projects: ablation and flow studies by Sellmann and a study of structure by Rutter. A topographic map of the glacier was constructed by plane-table methods; it has a scale of 1:2000, 20-foot contour intervals and was completed by the middle of the summer. A triangulation net with altitudes was also completed in order to provide better control for flow and ablation studies. Liberal assistance was given by the U.S. Army Cold Weather and Mountain School, Fort Greely Alaska in providing air transport for establishing base camps.

Ablations studies. To obtain information on the rate of lowering of the ice surface a total of 6510 -foot wooden stakes of 1-inch diameter were set in the glacier. They were installed with the aid of a SIPRE ice auger and all held firm. However, resetting of stakes on the lower glacier was necessary. Measurements were made at all stakes at 10-day intervals and daily measurements on a few stakes for correlation with meteorological data, which were recorded daily throughout the summer. Additional stakes were set in the glacier where ice thickness and type of morainic cover on the ice varied. It was found that the total summer lowering of the clean ice surface was 15 feet near the terminus and 17 inches in the upper parts of the glacier.

Movement. The ablation stakes were also used for movement studies. Controls were set up on the various ice streams composing the glacier. The stakes were surveyed with a theodolite at the time they were set, and again later to determine the amount of movement.

Two transverse profiles were established between the terminus and the ice falls. These will be used for an annual check of the actual level of the ice at these sections. Photographs were taken 
from established photo stations that had been occupied at various times during the last 50 years by Moffett and Péwé. Structure. The structural studies were directed mainly toward the mapping of foliation. Dips and strikes of the folia were mapped in detail with Brunton compass and fixed by bearings taken from known points. An arc pattern of foliation is displayed between the ice falls and the terminus; the dip of the folia becomes in general less steep down-glacier. In the main ice stream on the east an indistinct half-arc is present. Near the margin of the glacier, and adjacent to moraines the foliation is dense, with very steep dips.

Transverse, en echelon, splaying, and chevron crevasses were plotted with the aid of air photographs. Forbe's bands and sedimentary layers also occur and were plotted. A series of faults is present in the terminus and was mapped by plane table.

Geophysical measurements. Gravity measurements were taken along two controlled transverse sections by Rex Allen of the Branch of Geophysics, U.S. Geological Survey through the co-operation of David F. Barnes, Geophysicist. Glacial geology. Moraines of at least two recent advances were mapped. Lichenology was used exclusively for relative dating inasmuch as the area is above tree line. It is expected that the advances can be correlated with those in 1750 and 1850 of the Canwell, Castner, and Black Rapids glaciers to the north, where both lichen and tree-ring studies have been made.

Troy L. PÉWÉ

\section{A STUDY OF GLACIAL GEOMORPHOLOGY IN THE NORTHERN TORNGAT MOUNTAINS, LABRADOR}

This study was begun in 1959 and continued during the field season of 1960, when my wife Inger-Marie acted as assistant and we spent a little over 9 weeks in the field from early July to mid-September.

Base camp was set up at the northern end of Eclipse Channel and from there several journeys of 3- to 8-day duration were made. North Aulatsivik Island and the area to the north toward Telliaosilk Fiord were studied. Lack of a canoe prevented the crossing of Eclipse River, and the area to the south of it could therefore not be visited.

Study of the post-glacial emergence shows a discontinuous displacement of the strand-line. Three well-developed strand-lines were found at 40 to 56,26 to 36 , and 15.5 metres above sea-level. The two higher ones slope to N. $25^{\circ} \mathrm{E}$. at a gradient of $1: 1000$ and 1:1650 respectively for the higher and lower. Isobase-directions for these two levels are found to be approximately $115-$ $295^{\circ}$, and a map with contour lines showing the former sea-levels has been prepared. The lowest strand-line shows no tilt and is regarded as horizontal.

An equal-distance diagram has been plotted and shows that a major transgression took place in northern Labrador prior to the formation of the lowest strand-line. At Port Burwell the sealevel rose some 12 metres above the level it had during the formation of the next higher strand-line.

Fossil marine molluscs were found in the base-camp area up to 32 metres above sea-level. A shell sample taken at 29 metres has been submitted for radio-carbon dating through the Geographical Branch, Department of Mines and Technical Surveys. The result will provide the first absolute date for any late- or post-glacial event on the Labrador coast.

$\mathrm{Mr}$. V. Conde of the Redpath Museum, McGill University has kindly determined the molluscs and found a borealarctic fauna. Mya truncata, Hiatella arctica, and Astarte borealis are the dominant species.

Several terminal moraines were located, e.g., along Telliaosilk and Noodleook fiords, on North Aulatsivik Island, in the base-camp area, and Eclipse Valley. The study of strand-lines has made a correlation between them possible.

The maximum extent of the (last?) glaciation was studied and the upper trim-line and kame-terrace levels that have been found farther south ${ }^{1}$ were 